\title{
The Hanbalite Theology: A Critical Study of The Hanbalite Theological Creeds and Polemical Adversaries
}

\author{
DOI: https://doi.org/10.18196/afkaruna.v17i1.11353
}

\section{AHWAN FANANI}

Universitas Islam Negeri Walisanga

email: ahwan.fanani@walisongo.ac.id

\begin{abstract}
The Hanbalite school, well-known as a traditional school of Islamic law, played important role in theological disscourses in Islamic history. The fact, however, fails to be paid enough attention because of prevalent knowledge among Islamic society that the Hanbalite is only and a school of Islamic law. The Hanbalite theology is frequently abandoned in Islamic scholarship, although several researches have tried to reveal them. This article is aimed to extend previous researche of the Hanbalite theology through the description of its creeds and the elaboration of theological polemics between the Hanbalites and their adversaries. This article employs the history of idea by analyzing references written by Hanbalite scholars and other related sources. The references are collected and categorized according to the need of topics and then interpreted to provide readers with overall picture of the Hanbalite theology and their polemics along history. The Hanbalites creeds are based on textual understanding on Quranic texts and prophetic traditions. The creeds are underpinned by the idea that the Quran is not created and Quranic verses on God's attributes should be understood textually. The idea led Hanbalite scholars to do a debate with other theologians. The article provides a more vivid description on Hanbalite creeds and analyzes the creeds in the light polemics launched by the Hanbalite scholars against their rivals. The article, however, does not elaborate detailly on each Hanbalite scholar's contribution in forming sophisticated Hanbalite theology.

Key Word: Hanbalite, theology, creeds, polemics
\end{abstract}

\section{ABSTRAK}

Mazhab Hanbali, yang dikenal sebagai mazhab hukum dalam Islam, memainkan peran penting dalam wacana teologi dalam sejarah Islam. Akan tetapi, kenyataan itu kurang mendapatkan perhatian karena kuatnya persepsi di kalangan masyarakat 
muslim bahwa mazhab Hanbali hanya sekedar mazhab hukum. Teologi Hanbali seringkali diabaikan dalam kajian akademik, meski beberapa artikel tentang teologi Hanbali mulai muncul. Artikel ini dimaksudkan untuk memperluas penelitian sebelumnya mengenai teologi Hanbali melalui penggambaran lebih jelas kredo Hanbali dan penjabaran mengenai polemik teologi yang melibatkan para ulama Hanbali berhadapan dengan lawan diskusi mereka. Artikel ini menggunakan pendekatan sejarah ide melalui analisis berbagai karya yang ditulis oleh para ulama Hanbali dan sumber-sumber terkait. Referensi tersebut dikumpulkan dan dikategorikan sesuai dengan pembahasan serta ditafsirkan untuk menyediakan pembaca tentang gambaran mengenai teologi Hanbali dan polemik teologis mereka. Kredo Hanbali didasarkan atas pemahaman tekstual atas teks al-Quran dan hadis. Kredo tersebut dibangun di atas gagasan bahwa al-Quran bukan makhluk dan sifat-sifat Allah harus dipahami secara tekstual. Gagasan itulah yang menjadi titik polemik ulama Hanbali dengan ulama dari aliran teologis lainnya. Namun, artikel ini tidak menjelaskan lebih detail mengenai pandangan masing-masing ulama Hanbali dan sumbangsih mereka dalam pembentukan teologi Hanbali yang lebih maju.

Kata Kunci: Hanbali, teologi, keyakinan teologi, polemik

\section{INTRODUCTION}

Hanbalite is generally associated as a school of Islamic law, along with Hanafite, Malikite and Shafi'ite, but it involves in theological discourse along Islamic history. Ahmad Ibn Hanbal was a pioneer of traditionist movement againts rationalistic theology. ${ }^{1}$ George Makdisi noted two important moments in the development of classical Islamic scholarship. The first is the emergence of the Shafi'ite school of thought which succeeded in synthesizing reason and text so that the views of traditionists could be accepted by classical jurists. The second was the emergence of Ahmad Ibn Hanbal who successfully escaped of mihna and represented traditionists' theological views in front of officially imposed rational belief. ${ }^{2}$

At the beginning of his development, however, Ahmad Ibn Hanbal's authority as jurist was questioned by several scholars, such as Muhammad Ibn Jarir al-Tabari (d. 310/923 AD), who regarded him as a traditionist. Ibn Nadim (d. 377 H / 987 AD) and al-Maqdisi (375 H/ 985 AD) also categorized Amad Ibn Hanbal as traditionist (ashab al-hadith), along with al-Awza'i (d. 157 / 774 AD), Ibn Mundhir (d. 316/928M) and Ishaq Ibn Rahawayh (d. 151/768 $A D)$. Both scholars, however, put another traditionist school, namely zahirite, as the school of Islamic law at the end of the $10^{\text {th }}$ century AD. ${ }^{3}$

The Hanbalite as the school of Islamic law, however, received a wide 
acceptance so that Hanbalite school is always being included in the collection of sunni legal schools that encompasses the legal opinions of Hanbalite scholars in addition to the Malikite, Hanafite, and Shafi'ite scholars as can be seen in the comparative legal works like al-Fiqh 'ala Mazhahib al-'Arba'a. ${ }^{4}$ The Hanbalites, then, became one of established traditional school of Islamic law among Sunnite Muslims.

The existance of the Hanbalite as the school of Islamic law is also recognized by Islamic Organizations in Indonesia, such as Nahdlatul Ulama. Bahtsul Masail, a forum for resolving legal problems among Nahdlatul Ulama's followers, refers to the work of several Hanbalite scholars, such as Ibn Taymiyya (d. 728 H / 1328 AD), Ibn Qayyim al-Jawziyya (d. 751 H / 1350 AD), Abu Ya'la al-Farra' (d. 458H), Shams al-Din Ibn Muflih al-Maqdisi (d. 763H/ 1362 AD), 'Ali Ibn Sulayman al-Mardawi (d. 885 H / 1480 AD) and Mansur Ibn Yunus Ibn 'Idris al-Bahuti (1051 H/ 1641 AD). ${ }^{5}$ Ibn Taymiyya and Ibn Qayyim had influence in the idea of coming back to the Qur'an and the Prophet traditions, opening the door of ijtihad and puritanism in modern Islamic movement, such as Muhammadiyah di Indonesia. ${ }^{6}$

Hanbalite played important is not only a school of Islamic law, but it also plays an important role in theology. Ahmad Ibn Hanbal was celebrated as a defender of traditionist position in their opposition to the force of Mu'tazila imposed by the Abbasid rulers in the era of al-Ma'mun (d. 218H / 833AD, al-Mu'tasim (d. 227H / 842AD) and al-Wathiq (232H / 847AD). Hanbalite gained the reputation as ahl al-sunna school, an ortodox Islam. ${ }^{7}$ In the $11^{\text {th }}$ century, Hanbalite was recognized as an independent theological school. ${ }^{8}$

Hanbalite differs from other legal schools because of its position as both legal and theological schools. Most Hanafite adhere to Maturidite theology, while the majority of Shafi'ites and some Malikite follows Ash'arite's creeds. Hanbalite scolars, however, do not need to adhere to any other theological schools because Hanbalite acts as theological school as well. Eventhough well-known as jurists, Hanbalite scholars, such as Abu Ya'la, Ibn 'Aqil, and Ibn Qudama wrote theological treatises and involved in theological debate with other theologians. Such theological debate was not new phenomenon in Hanbalite as Ahmad Ibn Hanbal wrote several theological treatises, such as Kitab al-Sunna and al-Radd 'ala al-Jahmiyya wa al-Zanadiqa.

The theological attitude of the Hanbalite school is influenced by the idea of Ahmad Ibn Hanbal. Ahmad Ibn Hanbal rose as theologian because of his opposition to mihnah (inquisition) conducted by Abbasid caliphs. Mihna was 
the official stance taken by the Caliph al-Ma'mun in $212 \mathrm{AH} / 827 \mathrm{AD}$ to promote a creed that the Koran is creature as stated by Mu'tazila scholars. AlMa'mun's policy sparked opposition from conservative clerics in $218 \mathrm{AH}$ / $833 A D$ when he ordered the provincial governors to ask religious scholars to conform to this idea and that the conformity was a condition for the application for an employee chair. Ahmad Ibn Hanbal, along with Muhammad Ibn Nuh, opposed the policy that led to their arrest and imprisonment. ${ }^{9}$

The opposition made Ahmad Ibn Hanbal popular as defender of the sunna and the stance of Sunnis majority. His struggle to face mihna attracted followers and shaped theological basis for Hanbalite theology. Unfortunately, the theological stance of Hanbalite was not elaborated detailly yet by scholars due to the attribution of Hanbalite as Islamic school of law by Khan, al-Jaziri and 'Uthaimin. ${ }^{10}$ The works on Hanbalite mainly focuse on its legal thought or on hadith study.

There are, however, some previous researches on Ahmad Ibn Hanbal's opposition against rationalistic theology. Melchert wrote articles on "The Advesaries of Ahmad Ibn Hanbal"11 , "Ahmad Ibn Hanbal and the Qur'an", 12 and "The Hanabila and the Early Sufis.". ${ }^{13}$ In first article, he provided the depiction on Ahmad's disputes with rationalist and semi rationalist. He positioned Ahmad Ibn Hanbal as traditionist who opposed rationalists' camps on their reliance on opinions rather than hadits reports and their idea that the Quran is creature and the pronunciation of the Quran as creature as well. He also addressed his critics toward Shi'a hostility toward prophets' companions.

In second article, Melchert highlights Ahmad Ibn Hanbal's position on the recitation of the Quran and the position of the Quran in legal thinking. In third article. he elaborates Hanabila hostile critics toward sufis, especially Sari al-Saqati and al-Muhasibi, on their engagement in theology and their performing dhikr collectively. However, Melchert does not provid the explanation on Ahmad Ibn Hanbal's creeds further because his aims was to show the difference between Ahmad Ibn Hanbal form his advesaries.

Azmeh and Williams highlight rigorous religiosity that Ahmad Ibn Hanbal embraced. Al-Azmeh considered him as the proponent of fideism (anti-rationalistic idea), especially on God's attributes. ${ }^{14}$ Williams does not agree to Azmeh's conclusion on Ahmad's fideism, rather he prefer to categorizing Ahmad as minimalist fideism proponent for his limited employment of rationalism and interpretation. Anthopomorphism initially flourished under Ahmad 
Ibn Hanbal patronage, but it come to be alternative view available for muslims to interpret important pillars of Islam. ${ }^{15}$

This paper aims to reveal the theological creeds held by the Hanbalite and to provide vivid picture of theological polemics launched by Hanbalite scholars. The development of theological idea of Hanbalite is a contributive point that the article offers to academic readers. The article is to deepens the insight into the body of Hanbalite creeds in the light of long history of polemics carried out by Hanbalite scholars to their opponents. The understanding of the development of Hanbalite creed will reveal the reality that Hanbalite schools acts as the school of Islamic law and the school of theology, the fact that is rarely paid close attention.

The article uses a historical approach through library research to give a description of the development of Hanbalite creeds. The article scrutinizes Hanbalite theological works written by Hanbalite scholars to describe the Hanbalite's creeds and to portray the polemic conducted by Hanbalite scholars againts their opponents. The data are collected and categorized according to the squence of narration and interpreted to provide clear description of the Hanbalite creeds and analyses of their arguments in the polemics againts their opponents. The article, therefore, provides a diachronic explanation to the evolution of Hanbalite creeds through theological debate against their theological proponents. ${ }^{16}$

\section{THE DEVELOPMENT OF HANBALITE MADHHAB}

The Hanbalite school is associated to its founder, Ahmad Ibn Hanbal. During his lifetime, he was recognized more as an traditionist (muhaddith) than a jurist (faqih). He was also well-known for his opposition against the Abbasid rulers who imposed a belief on the Quran as creature. The career leads a historian Ibn Jarir al-Tabari to not include him as a jurist. ${ }^{17}$

The recognition of Ahmad Ibn Hanbal as a jurist initially came from Hanbalite scholars. Abu Ya'la (d. 458H / 1065M), a well-know Hanbalite jurist, quoted the words of Rabi' Ibn Sulayman (d. 270 / 883M), a student of al-Shafi'i, who reported the recognition of al-Shafi'i on Ahmad Ibn Hanbal's expertises in eight fields, including in Islamic law (al-Imam fi al-Fiqh), although al-Shafi'i respected Ahmad Ibn Hanbal's expertise in hadith and rijal (hadith narrators). ${ }^{18}$ Ahmad Ibn Hanbal refused his opinion to be recorded and emphasized a direct reference to the Quran and sunna instead. However, his students recorded his various fatwas in Masa'ils works that provide early 
compilation of Hanbalite legal opinions. ${ }^{19}$

The Hanbalite school developed from Baghdad, the birthplace of Ahmad Ibn Hanbal. The Hanbalite School developed and competed with other legal schools until it was recognized as an independent legal school in the $10^{\text {th }}$ century. The appointment of Abu Ya'la as a judge accelerated the development of Hanbalite so that its influence expanded to Syria in the $10^{\text {th }}$ century and to Egypt in the $12^{\text {th }}$ century. The development of Hanbalite in Egypt began with the appointment of al-Hajjawi as a judge during the late Ayyubid reign (1171-1250 AD). The development of the Hanbalite School was not as fast as three other schools because it was never adopted as an official school by any political power. The Hanbalite school again gained strong position in the Kingdom of Saudi Arabia and Qatar in modern time..$^{20}$

There are several figures who played important role in the development of the Hanbalite. Al-Kawsaj (d. 251/865 AD) was a narrator of Masa'il Ahmad Ibn Hanbal who traveled to Hijaz, Syria, Iraq and finally settled in Nisabur until he died. Ahmad Ibn Hanbal's son, Salih Ibn Ahmad (d. 266/880 AD), served as judge in Tarsus and Isfahan. Abu Salih Muflih (d. 330942 AD) developed the Hanbalite school in Damascus. Abu al-Qasim al-Khiraqi (d. $334 \mathrm{H} / 945 \mathrm{AD}$ ) acted as writer of standard works of the school. He settled in Damascus during the Buwaihi influence in the Abbasid caliphate.

Prominent Hanbalite figures appeared, such as 'Abd al-Wahhab al-Harrani (d. $476 \mathrm{H} / 1083 \mathrm{AD}$ ), a judge, mufti and teacher of the Hanbalite. In Isfahan, the names of several Hanbalite figures emerged, such as Abu al-Qasim (d. 360/971 AD), Abu 'Abd Allah Ibn Manda al-Isfahani (d. 395/1005 AD) and Abu al-Qasim Ibn Manda al-Isfahani (d. 470 / 1078M). In Amid (present day: Diyarbakir, Turkey), there were 'Abd al-Rahman al-Baghdadi (d. 468/1075) and Abu al-Qasim Ibn Abi Ya'la (d. 469/1077 AD). In Herat, there was a famous Hanbalite figure, 'Abd Allah al-Ansari al-Harawi (d. 481/1088 AD). Meanwhile in 'Ukbar, Ibn Batta al-'Ukbari (d. 387/997 AD), Abu Hafs al'Ukbari (d. 339/950 AD) and Abu al-Husayn al-'Ukbari (d. 424/1033 AD) appeared as outstanding Hanbalite figure in early $10^{\text {th }}$ Century. ${ }^{21}$

The emergence of Hanbalite was a monumental victory of traditionists in Islam over rationalists. ${ }^{22}$ The recognition of Hanbalite as the school of Islamic law took place subsequent to mihna during the Mutawakkil era until the emergence of Buwayhid Dynasty (855-945AD / 241-334 H). Hanbalite involved in the confrontation againts Imami Shi'ites, supported by the Buwayhids. Buwayhid Dynasty strengthened Isma'ili Shi'a in Egypt during the Fathimid 
dynasty (358 H / 969 AD). Hanbalite figures had increasingly a decisive influence during the restoration of the Sunni era of al-Qadir (381-422 H / 991 1021 AD) and played role as the defender of the caliphate and the Sunni groups. ${ }^{23}$ The last two centuries of the Abbasid rule in Baghdad (447-656/ 1061-1258) were the golden age of the Hanbalite school.

At the end of the Abbasid era, outstanding masters emerged among the Hanbalite. The first was Ibn Hubayra, prime minister of the Caliph al-Muktafi (from $554 \mathrm{H} / 1149$ AD), who established Hanbalite in $557 \mathrm{H}$. The second was Abd al-Qadir al-Jaylani (d. 561 H/ 1666 AD), the founder of Qadiriya's brotherhood and celebrated as prominent saint in Islamic world. The third was Abu al-Faraj Ibn al-Jawzi (597H / 1200AD), a legal and hadith expert, who studied with many Hanbalite masters and wrote several works rejecting Sufis' practices and philosophers. ${ }^{24}$

The important development of the Hanbalite in Syria were influenced by Ibn Munajja's and Bani Qudama's family. Bani Qudama contribute to the development of the Hanbalite school through 'Abd al-Ghani, an Ash'arite Sufi and Muwaffaq al-Din Ibn Qudama. In Harran, a region near Damascus, there was also the center of Hanbalite from the beginning, with Majd al-Din Ibn Taymiyya (d. 652 / 1254-1255), the grandfather of Ibn Taymiyya. Under the Mamluk Bahriya and 'Uthmaniyya Reign, the Hanbalite was still active in Syria and Palestine, with the prominent figures Ahmad Ibn Taymiyya (d. 728 / 1326 AD), Ibn Qayyim al-Jawziyya (d. 1350AD) and Ibn Rajab (d. 1393AD). Under the Mamluk Circasian (784-923 H/ 1382-1517 AD), the Hanbalite began to lose its importance in several cities, as a result of their opposition to Ibn 'Arabi, whose influence was increasing at that time in Syiria, Palestine, Nisabur, Ray and Isfahan. ${ }^{25}$

\section{AHMAD IBN HANBAL'S THEOLOGICAL THOUGHT}

\section{The Attitude Toward Theologians}

Ahmad Ibn Hanbal reflected traditionists who did not prefer the use rational arguments $\left(r a^{\prime} y\right)$ in legal and theological disputes. He rejected legal teaching without direct reference to hadith or the opinions of Prophet's companions. His opposition to the ra'y was strong that he condemned person who issued fatwas based on hiyal (rational manipulation) as infidel. He included ashab alra'y (jurits who inclined to use ra'y) in the theological groups that he rejected, namely Murji'a, Qadariya, Rafida, Hawarij and Jahmiya. He excluded those theologians, especially Rafida, from Islamic community. ${ }^{26}$ 
Ahmad Ibn Hanbal opposed the proponents of ra'y who held the idea that the Quran is created. The opposition to the idea was central in Ahmad Ibn Hanbal's thought. He labelled those who believed that the Quran is creatured and who rejected the attributes of God as Jahmiya. Ahmad Ibn Hanbal requested them to repent, otherwise they might be killed. ${ }^{27}$

Ahmad Ibn Hanbal's attitude towards theologians (mutakallimin) was harsh. He forbade his students to sit with those who claimed the createdness of the Quran and deemed the claim as bid'a (innovation). He criticized his friends who studied with al-Karabishi (d. $245 \mathrm{H} / 862 \mathrm{AD}$ ) and Abu Thawr (240 / 854M), both of which considered the recitation of the Quran as created. Interestingly, Ahmad highly praised Abu Thawr for his expertise in hadith. ${ }^{28}$ Ahmad Ibn Hanbal's criticism was not only directed at theological arguments, but also at rational arguments. He prohibited the use of logical arguments to defend Islamic faith.

Although Ahmad Ibn Hanbal appreciated the practice of Sufism and wrote the book al-Zuhd, his attitude towrd sufis was not hospitable. Ahmad respected Ma'ruf al-Karkhi (d. 200 / 815-16 AD) for his mastery in hadith. However, he did not like al-Harith al-Muhasibi (d. 243/857- 58) because of his rational theological thought. Al-Muhasibi had to hide from the Hanbalite threat and his funeral was only attended by four people. ${ }^{29}$

His opposition to the belief that the Quran was created as promoted by the Abbasid Caliph since al-Ma'mun (d. 833 AD), al-Mu'tasim (833 - 842) until al-Wathiq (842-847) brought him into jail for 28 months in Bagdad during the reign of al-Mu'tasim. After released, he was forbidden to teach until the regime of Caliph Mutawakkil (847-861 AD) who sought support from him. ${ }^{30}$ Traditionists were targeted at mihna - inquisition held by Abbasid rulers - due to their persistance not to comply government's request. ${ }^{31}$

The opposition of Ahmad Ibn Hanbal to mihna drew wide support from mass and scholars. The resistance to the mihna and to the followers of Jahmiya was also directed by a mob to officials after the death of al-Mu'tasim and the rise of al-Wathiq (227-232 / 842-847 AD). The mob beat two of Jahmiya's followers and removed a sign promoting the createdness of the Quran from a private mosque in Baghdad. Ahmad Ibn Hanbal, however, refused to support violent resistance to the Abbasid goverment.

The struggle of Ahmad also drew support from other Mu'tazilah insider, namely Abu Hasan al-Ash'ari (d. 324 H/ 935-6 AD). He had been a follower of Mu'tazila before he chose to support Ahmad Ibn Hanbal's movement and 
celebrated Ahmad Ibn Hanbal's opinion as the representation of the truth (alhaqq) and sunna. Al-Ash'ari, who belonged to Shafi'ite background, abandoned Mu'tazila later and founded his own theological school. ${ }^{32}$ Al-Ash'ari critics against Mu'tazila's creeds in his al-Ibana led Makdisi to conclude that he was a traditionists and Hanbalian as well. ${ }^{33}$ Al-Ash'ari's approach, however, was not always in line with Hanbalite's one. Although praising Ahmad Ibn Hanbal in his work, his method of argumentation differed from that of Hanbalite. ${ }^{34}$

Abu Hasan al-Ash'ari called Ahmad Ibn Hanbal's proponents as ah/ alhaqq wa al-sunna whose creeds were: "Allah is One, Muhammad is His messenger, heaven and hell are true and Allah will raise those in the grave". AlAsh'ari embraced the idea that Allah reigns (istiwa') in 'arsh and has face and hands without necessarily explaining how (bila kayf) as traditionists usually hold. According to him, whoever thinked that Allah's attributes are other than Him, he had lost his way. ${ }^{35}$ Ignaz Goldziher saw the creeds were aimed to counter to Mu'tazila's. While Mu'tazila rejected a literal understanding on the attributes of the God, the Hanbalite held the imperative position to hold textual interpretation on it, such as hearing, seeing, standing and sitting, without necessarily questioning how God does it (bi la kayf). ${ }^{36}$

Although supporting Ahmad Ibn Hanbal, al-Ash'ari criticized him in his other works. According to Amin, al-Ash'ari's support to Ahmad Ibn Hanbal was an effort to gain the support from wider community members. The literality of Ahmad Ibn Hanbal and traditionists' theology was incompatible to the rational background of al-Ash'ari, who chose to defend Islamic ortodoxy by both textual and rational arguments. The critics marked the methodological break between al-Ash'ari, followed subsequently by the Ash'arite, and traditionists, especially Hanbalite. ${ }^{37}$ The break led to long disputes between Ash'arite proponents and the Hanbalites, both of which claim to be the representation of ahlal-sunna camp.

\section{The Creeds of Ahmad Ibn Hanbal}

The theological thoughts of the Hanbalite stemmed from and were strongly influenced by the views of Ahmad Ibn Hanbal. Abu Ya'la at the end of his Tabaqat al-Hanabila presented a chapter on Ahmad Ibn Hanbal's creeds. The creeds highlighted and systematisized the pillars of Hanbalite theology, especially on God's attributes and human actions. 


\section{a. God's Attributes}

God's attrributes are central issues in Islamic theology. The schools of Islamic theology embrace different stances on the God's attributes. Mu'tazila, for instance, was known as a supporter of an absolute monotheism and insisted on the inseparability between God's attributes and His substance. Mu'tazila emphasized the Oneness of God so that His various attributes might not be seen as independent entity from His Essence. However, God has different names mentioned in the Quran, which are parallel to His attributes. The discussion about the relationship between His Oneness and the variety of His names sparked heat debate among Islamic theologians. ${ }^{38}$

According to Watt, the debate on God's attributes is a continuation of the previous debate about the Quran beginning in 750 AD. The Qur'an is the logos or the word of God as stated in the Quran sura al-Zukhruf verse 3: "We actually made the Quran in Arabic so that you can understand it." The verse opens different interpretations whether the Quran is a creature or it has divine character. $^{39}$

Ahmad Ibn Hanbal recognizes all attributes of God mentioned in the Quran. God's attributes, according to him, might be known through the information of The Quran. Every attribute has unique meaning, such as al-Sami' (AllHearing) and al-Basir (All-Seeing), both of which are unique. He accepts literal meaning of the Quran, such as the God has a face. The face of God is real, unimagined and eternal. The God also has two hands, but they are not members of any body and are not composed of any element. Whoever claims that God's face is He Himself, he has deviated from true teaching of the Quran. People who refuses to accept God's attributes will turn to be apostate. $^{40}$

Ahmad Ibn Hanbal's explanation on Allah's attributes may lead to suspicion that he embraces an anthropomorphic tenet, as Patton and Anawati do. ${ }^{41}$ Hanbalite has been accused by its opponents as the follower of the Mujassima (anthropomorphism). However, several scholars, such as Laoust, Strothmann and Watt, refused the accusation since Ahmad is the representation of the orthodox camp, rather that of the anthropomorphist. Wesley William consider anthromorphism a choice among the Sunnists at the beginning of its development. The anthromorphism was not only as the result of literal understanding of the Quran, but it is also a kind intellectual perspective. ${ }^{42}$ In fact, Ahmad realized that anthromorphic attributes of God in the Quran constituted metaphorical understanding and they do not refer to any physical 
form. ${ }^{43}$ He refuses to interpret those attributes methaphorically and avoids theological speculations as well.

Ahmad Ibn Hanbal insistently refuses to give any chance to the idea that the Quran is created. He said: "a creature is created with all its characteristics, while Allah is not creature with all of His attributes." On the question of whether the letters of the Quran are identical to their reference, Ahmad and traditionists would answer "We don't know" 44 , as the manifestation of bi la kayf position.

\section{b. God's Justice and Human Actions}

Ahmad Ibn Hanbal included justice as God's attribute, without reducing His power. According to him, if God wanted to get rid of any human action that He does not like, He would do it because He would never be forced. His justice is not determined or grasped by human reason and His deeds are not created as well. Ahmad Ibn Hanbal challenges the second principle of Mu'tazila, namely God's absolute justice, which obliges God to show his justice by freeing human from responsibility for actions they have no determination to do them. Mu'tazila holds idea that God will never punish human for actions they are not responsible to. ${ }^{45}$ This idea contradicts to that of Ahmad Ibn Hanbal who hold the absolute power and will of the God.

He avoided debate on whether a faith was created or not. He blamed who regarded the createdness of the faith as heathen (unbeliever) and considered who assumed it the uncreated as heretic because the discussion on God's attributes were not explained in Quran or prophetic traditions. ${ }^{46}$ This principle was followed by Ibn Taymiyya in his al-'Aqidah al-Hamawiyya that brought him into trial in Egypt and Damascus. ${ }^{47}$ Ibn Taymiyya highlighted the idea of Hanbalite and traditionists on the issue.

Ahmad distinguished between belief and Islam, based on the popular hadith regarding belief (iman), Islam and ihsan and the content of Surah alHujurat 14, concerning God's rejection of Bedouin's claim that they had been believers. The difference between belief and Islam is that the former is justification on faith and the latter is an manifestation of the submission of human to their God. A Muslim would not be an infidel because of their sins, except for abandoning obligatory five prayers, in which the doer deserved to be punished by death sentence. ${ }^{48}$ The thought differed from that of the Khawarij who argued that a muslim who committed serious sins would be an infidel and any ruler who was not line with Allah's law should be fought against. ${ }^{49}$ 
For Ahmad Ibn Hanbal, Allah would forgive the sinners according to His deliberate choice.

Ahmad Ibn Hanbal creed comprises many other issues. He discusses on graves, legal arguments, rituals, leadership, bid' or innovation, human effort (kasb), karama (magical power) of saints, and hadith experts. He, for instance, believes in life in the grave and believe that the Prophet also lived in their graves. He also holds belief that Allah punishes people in their graves due to their sins.

Ahmad Ibn Hanbal prefers political stability than radical political change. He supports status-quo on political leadership (imama). For him, conflict against a ruler should be avoided eventhough he conducted wrong policy. He considered prayer behind of an injustice leader as legitimate because Ibn Umar prayed Friday and 'Id behind al-Hajjaj (who was notoriously brutal). Consequently, he forbade his fellow Muslims to disobey political leaders, as far as they did not stated that the Quran was created and did not belong to qadariya creed.

Ahmad Ibn Hanbal wrote theological treatises rejecting the creed of the Jahmiya, the Qadariya and the Zindiq regarding to their creeds on the Quran, leadership (imama) and ahl al-bayt (prophet family). Ahmad Ibn Hanbal's son, 'Abdullah, had a treatise on al-Sunna, while Abu Bakr al-Khallal collected inter-religious topics attributed to Ahmad Ibn Hanbal under title Ahkam Ahl al-Milal min al-Jami' li Masa'il al-Imam Ahmad Ibn Hanbal. ${ }^{50}$ The creed of the Hanbalite attracted Islamic scholars, such as Abu al-Fadl Muhammad Nasir al-Sulami (d. $550 \mathrm{H}$ ), who abandoned Shafi'ite and, instead, chose the Hanbalite due to theological reason. ${ }^{51}$

\section{THE DEVELOPMENT OF HABALITE THEOLOGY}

The writing on theological issues was developed among the Hanbalite after the era of Ahmad Ibn Hanbal. The Hanbalite had outstanding figures who were interested in theological discussions, such as Abu Ya'la al-Farra', Ibn 'Aqil, Ibn al-Jawzi, Ibn Mibrad, Ibn Taymiyya and Ibn Qayyim. Their writings shaped Hanbalite theological characters and had the Hanbalite not only as legal school, but also as theological one. This stance made the Hanbalite differed from other Islamic law schools who focused on legal opinions. A Shafi'ite would put additional attribute of theological school in their name to show their theological orientation because not all of Shafi'ite are Ash'arite. Abu Ishaq al-Shirazi (d. 467H 108 3AD) was an example of a Shafi'ite who 
was not an Ash'arite. He conducted theological debate with Abu Ma'ali alJuwayni (d. 478H/ 1085AD), a Shafi'ite-Ash'arite figure, on theology. ${ }^{52}$ Hanbalite scholars, in other hand, did not need to show theological affiliation because the Hanbalite represented theological affiliation as well as legal school.

Abu Bakr al-Khallal (d. 311 H/ 923M) collected various legal and theological issues attributed to Ahmad Ibn Hanbal in his Ahkam Ahl al-Milal. The book contained legal issues regarding ahlal-kitab, such as on rituals, almgiving (zaka), law of ah/ al-dhimmah (non-Muslims under the protection of Muslim), the settlement of disputes between dhimmi (protected non-moslems) and his fellow, marriage, slaughter, punishment, siyar (war) and apostasy. The book opened with special chapter on theological issues under Kitab alIman. ${ }^{53}$

After Ahmad Ibn Hanbal passed away, the Hanbalite continued to preserve his main creeds. Ibn 'Aqil stated that he was follower of Ahmad Ibn Hanbal's creed and Ibn Taymiyya notified that the Hanbalites followed the path of their predecessors. ${ }^{54}$ The theological discourses among the Hanbalite went around the topics discussed by Ahmad Ibn Hanbal previously, although they added some supportive arguments. Al-Barbahari (d. 941 AD) developed the idea of bila kayf (without how) suggesting that people were not be able to describe how God's attributes work. God should be described according to what He himself had described without questioning on "how" and "why". Al-Barbahari attributed this view to Malik Ibn Anas (d. 795 AD) who said that istiwa ' (the residing of Allah in the Throne) was known (ma'lum), but the way was unknown (majhul). The belief on the istiwa' was an obligatory, but the question on "how" was a heresy. ${ }^{55}$

Al-Barbahari wrote Sharh al-Sunnah a small treatise on propethic traditions. The treatise emphasized that Islam is sunna and the sunna is Islam, both of which should not be separated. The sunna confirmed bila kayf idea so that God's attribute could not be explained why and how. He rejected rational discussion on the topic that he condemned it to be an innovation (bid'a) and heresy. Al-Barbahari restated Ahmad Ibn Hanbal idea that The Quran was not created by referring to the authority of Malik, Ahmad Ibn Hanbal and classical jurists. ${ }^{56}$

Another celebrated Hanbalite figure was Abu Ya'la al-Farra' (458H / 1065AD). He wrote al-Mu'tamad fi Usul al-Din which provided various theological topics, such as the law of reasoning, the knowledge of God, the attributes of Allah, spirit, reason, the actions of human (kasb), jin-devil-an- 
gels, mizan, sirat (a path in hereafter), grave punishment, heaven, faith, commanding good and forbiding evil, extremists from the Shi'a Rafida and the interpretation of metaphore. The treatise of Abu Ya'la gave a picture of Hanbalite's attitudes towards other schools, especially those who were deemed as infidle based on the consensus of Muslims, namely the Dahriyah (belief in time); philosophers; the Brahmins who rejected the messengers of God; worshipers of idols, stars and fire; and Jews and Christians.

The cathegory also included Islamic theological schools, such as Qadariya, Mu'tazila and Jahmiya based on their claims that al-Quran was creature. Some schools, like Murji'a who embraced the idea that true faith was based on statement. The Khawarij were differentiated by the Hanbalite between those who believed in 'Usman Ibn 'Affan (d. 35 / 656M) and 'Ali Ibn Abi Talib (d. $41 \mathrm{H} / 661 \mathrm{AD}$ ) and those who did not. The latter was considered infidel, so did Rafida. ${ }^{57}$

Ibn Qudama, a great jurist of the Hanbalite, was another outstanding theologian. He wrote Lum'a al-I'tiqad presenting the general creeds of the Hanbalite. ${ }^{58}$ The tiny treatise talked about main Hanbalite's or salaf's creeds based on classical authorities, such as Ahmad Ibn Hanbal, Muhammad Ibn Idris al-Shafi'i, Ibnu Mas'ud, al-Awza'i and 'Umar Ibn 'Abd al-'Aziz. The treatise discussed God's attributes, the Quran as the word of God, seeing God in the hereafter, qada and qadr (human destiny), the embodiment of faith in words and deeds, belief in Prophet's teachings, and Muhammad as the last prophet. The work was typical of the Hanbalite's, filled with the quotations from the Quranic verses and prophetic traditions. The work was later elaborated by Muhammad Ibn Saih al-'Uthaymin (d. 2001 AD), a prolific Saudi Arabian scholar. ${ }^{59}$

In sum, Hanbalite creeds encompassed the topics the God's attributes, the Quran as divine words the interpretation of the Quran and the embodiment of belief in both statement and deeds. The topics stemmed from Ahmad Ibn Hanbal polemic against theologians and subsequent elaboration of Hanbalite scholars of Ahmad's creeds. The formulation of the Hanbalite creeds, then, were influenced by the disputes conducted by their scholars againts other theologians and sects.

\section{THEOLOGICAL POLEMICS}

Theological polemic formed theological ideas in Islam. The polemics among scholars used to be carried out through jadl (debate) and munazara (discus- 
sion). Munazara emphasized on the seeking of true knowledge through collective discussions, while jadal was oriented to defend a belief or opinion. Islamic scholars wrote several works on jadl and munazara to provide other scholars with guidance on how to conduct both in the discussion on Islamic law or theology. There were popular works on the topic, such as al-Ma'una fi al-Jadal by Abu Ishaq al-Shirazi, al-Jadal fi al-Usul by Abu al-Wafa' Ibn 'Aqil and al-Kafiya fi al-Jadal by Abu Ma'ali al-Juwayni. According to Widigdo, ${ }^{60}$ jadl was not only a kind of debate but it also served as the test of argumentation and reasoning because the jad/ was aimed to re-examine the validity of the arguments.

The polemic on theological issue in Hanbalite was, again, pioneered by Ahmad Ibn Hanbal. His opposition against mihna was starting point for the formulation of Hanbalite creeds. ${ }^{61}$ He also launched critics againts other Islamic sects. The Hanbalite also fought fiercely against the Syi'a with the support of the Caliph al-Qahir in 321 H/ 933 AD. Al-Barbahari was the celebrated figure who fought against Shi'a until his death in 329 H/940 AD. ${ }^{62}$ Afterward, several Hanbalite scholars follow the path, such as Abu Ya'la and his disciple Abu Ja'far, Ibn Qudama and Ibn Taymiyya, to defend Hanbalite creeds.

\section{Abu Ya'la and Abu Ja'far}

The polemic between the Hanbalites and the Ash'arites took place from 429H/ 1038AD until 445H/ 1053AD. Ash'arite scholars comdemned Abu Ya'la's understanding of God's attributes as kind of tashbih (anthromorphic), especially in his Kitab al-Sifat (Kitab Ibtal al-Ta'wilat li Akhbar al-Sifat). Abu Ya'la, however, got support from Shafi' ite traditionist, Abu Hasan al-Qazwini, who accompanied him before the trial by Caliph al-Qa'im. After the consultation to Shafi'ite judge, Abu Tayyib al-Tabari (d. 450H/ 1058AD) and judges from other schools, the Caliph decided to approve the work. ${ }^{63}$

Abu Ya'la divided religious law into three cathegories: first of which are known only by reason, such as the inevitability of the Creator. The second was not be formulated by reason, rather by sam' (transmission), such as religious obligations and prohibitions. The third employed both rational arguments and transmission (the Quran and hadith), such as the possibility of seeing God with eyes in Hereafter and the forgiveness for believers. ${ }^{64}$

Abu Ya'la involved in a polemic against an Ash'arite scholar, Ibn Furak (d.1015AD), regarding the interpretation of figurative speech (ta'wil) of God's attributes. This topic marked the break between the Hanbalites and the 
Ash'arites. Abu Ya'la wrote Kitab al-Sifat in response to the work of Abu Bakr Ibn Furak (d. 406 H/ 1015AD), entitled Ta'wil al-Akhbar. ${ }^{65}$ The conflict between the Hanbalites and the Ash'arites broke in 469/1077 when 'Abd alKarim al-Qushayri (d. 1074AD), an the Ash'arite propagandist, received an award at Madrasa Nizamiyya and gave a lecture at the Nizamiyya Gate. He promoted the Ash'arite's creeds and deemed the Hanbalites as mujassima (anthromorphist).

Al-Qushayri's statement sparked protests from the Hanbalites led by Abu Ya'la's disciple, Abu Ja'far (d. 470 H). In return, the Shafi'ite-Ash'arite proponents attacked Abu Ja'far $(\mathrm{d} .470 \mathrm{H})$ at his mosque, which prompted the Hanbalites camp to retaliate, drawing them into street fight with the Ash'arites and causing the death of a tailor, hit by stone. The clash led Wazir Nizam alMulk (d 1092 AD) to intervene and to end it with the imprisonment of Abu Ja'far who refused to reconcile. ${ }^{66}$

The rivalry between the Hanbalite and the Ash'arite was inseparable from the efforts of the Ash'arite to penetrate into the Shafi'ite school of law. By this effort, Ash'arite would have legitimacy in Islamic orthodhoxy, while they developed rationalistic approach, especially as had been done by Abu Ma'ali al-Juwayni as well. ${ }^{67}$ The Hanbalite, in other hand, concerned to prevent the penetration of Mu'tazila into the Hanafis ${ }^{68}$ and worried to rationalistic tendency among the Ash'arites. The polemic between the Hanbalite and the Ash'arite was inevitable as result of their different approaches to deal with theological issues as well as their competition to get legitimacy as the representation of Islamic ortodoxy.

Hanbalite scholars also clashed with Hanafite-Mu'tazili cleric Abu 'Ali Ibn Walid in 456H/1063AD. This clash led to the recitation of al-I'tiqad al-Qadiri before the meeting of the clerics. The Hanbalite also moved against Ibn 'Aqil in 461 H/1069AD under Abu Ja'far's leadership. Ibn 'Aqil was well-known as Hanbalite, but his scholarship history linked him with both the Hanbalite and the Mu'tazilite scholarship. Ibn 'Aqil was accused of being the sympathizers of Mu'tazila and al-Hallaj by Abu Ja'far, though the accusation was driven by Abu Ja'far's dissappointment of Abu Ya'la's decision to choose Ibn 'Aqil as his successor. Ibn 'Aqil fled and hid in Bab Maratib until the problem was resolved with his repentance in $465 \mathrm{H} / 1072 \mathrm{AD}$.

Hanbalite, along with Ash'arite and Mu'tazilite, was dominant wave of theological orientation in the $10^{\text {th }}$ and $11^{\text {th }}$ centuries AD. The three schools involved in competition to be authoritative reference among Islamic society. 
Al-Ghazzali tried to reconcile them by underpinning the acceptance of the Prophet's teachings as pillar of the true belief. He highlighted the diversity of creeds as natural phenomena, even inside Ash'arite. ${ }^{69}$

\section{Ibnu Qudama}

The core idea of Hanbalite theology lies on its resistance to rationalism. This resistance led to the polemic between the Hanbalites and the Mu'tazilite and between the Hanbalites and the Ash'arite. Ahmad Ibn Hanbal and many Hanbalite circles strongly rejected the use of ta'wil (metaphorical interpretation) on God's attributes. The opposition of Hanbalite toward ta'wil had them suffer of being accused as anthromorphists. ${ }^{70}$ The high-profile scholars among the Hanbalite who launched attacts on rationalism were Ibn Qudama and Ibn Taymiyya.

Ibn Qudama (d. 620H/1223 AD) is a master-jurist among the Hanbalites. His masterpiece, al-Mughni, is widely circulated and recognized as source for comparative study on Islamic law. He wrote Rawda al-Nazir wa Junna alMunazir, a work on Islamic jurisprudence. The works was written following the structure of al-Ghazzali's model of writing on al-Mustasfa. ${ }^{71}$ The interraction of Ibnu Qudama to al-Ghazzali's work did not mean that he agreed to Ash'arite creeds.

In his al-Munazara fial-Qur'an al-'Azim (1990), Ibn Qudama told his experience of carrying out munazara with people he referred to as ah/ al-bid'a (heretics). He wrote the treatise based on a request from his friends to prevent disinformation on the Quran. Ibn Qudama reinforced the idea that the Quran was the word of God, including the letters of the Quran. His opponents, however, argued that the letters were not the Quran, but creatures that signified the words of God. Ibn Qudama did not explain who he called them ahlal-bid'a, but it was presumably 'Abdullah Ibn Kullab (241 H/ 855AD), the predecessor of Abu Hasan al-'Ashari. ${ }^{72}$ Ibn Qudama refuted this opinion by quoting Ahmad Ibn Hanbal who remarked that whoever implied the Quran as a creature, he would be infidel.

The debate regarding the Quran extended to the topic of God's creature in which Ibn Qudama expressed his objection to the arguments of Jahmiya. Ibn Qudama cited a reportation on Abdullah Ibn Ahmad's question to Ahmad Ibn Hanbal about the Jahmiya who believed that God did not speak with voice. Ahmad answered that they had lied and had embaced the idea of the omission of God's attributes (ta'til). In his Ithbat Sifah al-'Uluw, Ibn Qudama 
reinforced Ahmad Ibn Hanbal's notion that Allah is on 'arsh based on prophetic traditions, the opinions of the companions and the opinions of classical authorities, such as Malik, Sufyan al-Thawri, Abu Hanifa, Muhammad alHasan (d. 189H / 804AD), Ibn Mubarak (d. 181H/ 797AD) and Abdullah Ahmad Ibn Hanbal. ${ }^{73}$

Ibn Qudama also wrote Tahrim al-Nazar fi Kutub al-Kalam to address Ibn 'Aqil's case. Ibn 'Aqil was an Hanbalite scholar who studied from both Hanbalite and Mu'tazilite teachers. Ibn Qudama's work was written after Ibn 'Aqil repented from Mu'tazilite orientation. Ibn Qudama reminded that if Ibn 'Aqil did not repent, he would be classified as a zindiq (heretic). He, however, praised Ibn 'Aqil's decision to repent and considered the repentance had had overcome his mistakes. He criticized the suspicions among the Hanbalites of Ibn 'Aqil as excessive and baseless attitude. Moreover, Ibn 'Aqil had written works on the rejection of ta' wil. $^{74}$

\section{Ibnu Taimiyah}

Ibn Taymiyya (728H / 1328AD) was the most prominent late Hanbalite figure after Ibnu Qudama. Ibn Taymiyya was an intelligent figure. However, he was undergoing several imprisonments due to his persistant defence on the salafi creeds. His work, Al-'Aqida al-Hamawiyah, brought him into trial before judges and a group of scholars, both in Egypt and in Damascus. He, however, managed to convinced the judges and scholars to accept his opinion, although he was imprisoned for his refusal to accept the judge's summons before and his refusal to speak in front of judges whom he considered not neutral. ${ }^{75}$

Al-'Aqida al-Hamawiyah was Ibn Taymiyya's answer to the question of Hama citizens in $798 \mathrm{H}$ about Quranic verses and prophetic traditions concerning God's attributes. ${ }^{76}$ This work provides theological arguments using the salaf (early pious generation of Muslims and scholars) perspectives. Ibnu Taymiyya rebutted the claim of people who supported khalaf (later scholars) approach employing ta'wil. He categorized the premises of the khalaf that ignored the Islamic sources as misleading premises.

Ibn Taymiyyah took different path from his predecessors who tried to defend Hanbalite creeds by means of pure textual arguments. In Dar' Ta'arud al-'Aql wa al-Naql, also known as Muwafaqa Sahih al-Manqul li Sarih alMa'qul, ${ }^{77}$ he employed a rational debate to support salaf creeds and falsified the arguments of rationalists, such as that of Fakhr al-Din al-Razi (d. 606H) 
1210AD), al-Amidi (d. 631H/ 1233AD), Ibn Kullab (d. 240H/ 854AD), alBaqillani, al-Ghazzali, Ibn Sina (d. 428H/ 1037AD), Ibn Rushd (d. 595H/ 1198AD), Ibn 'Arabi (d. 638H/ 1240AD) and Abu Hasan al-Ash'ari. Ibn Taymiyya classified al-Ash'ari in one camp with Ibn Kullab, al-Harith al-Muhasibi (d. 243H/ 857AD, al-'Abbas al-Qalanisi (d. 270H), Abu Bakr al-Sibghi (d. $342 \mathrm{H}$ ) and Abu 'Ali al-Thaqafi (d. 326H), although he praised al-Ash'ari's views in al-Maqalat al-Islamiyyin, al-Ibana and al-Luma' that were in accordance to salaf's creeds. Ibn Taymiyya's attacks were mostly aimed to al-Razi, Mu'tazilite circles, Jahmiya, philosophers and pantheistic Sufis. ${ }^{78}$

Despites of his affiliation to the Ash'arite, al-Razi inclined more to philosophy than al-Ghazzali did. ${ }^{79}$ Ibn Taymiyya presented 44 arguments to refute al-Razi regarding his priority of reason over religious texts. Al-Razi frequently refered to the Risala Adawiyya by Ibn Sina and reinterpreted it more freely according to his rational inclination. ${ }^{80} \mathrm{Ibn}$ Taymiyya criticized the rationalist inclination to put the reason higher than textual sources in his al-Radd 'ala al-Mantiqiyyin. The work criticized the principles of Aristotelian (traditional) logic he saw it unreliable. Ibn Taymiyya's critics were directed at three logical structures, namely the definition of terms, the proposition and the syllogisms. Ibn Taymiyya denied the superiority of logic for understanding religion as rationalists held, such as al-Ghazzali in his al-Mustasfa. ${ }^{81}$

He also criticized Abu Hasan al-Ash'ari, al-Ghazzali, al-Juwayni, Ibn Furak, Abu Ishaq al-Isfira'ini (d. 418H/1027-8 AD), and Abu al-Mu'in al- Nasafi (d. $508 \mathrm{H}$ ) as he also criticized Abu Ya'la and Ibn 'Aqil that supported the validity of traditional logic.82 Despite his critics to traditional logic, Ibnu Taymiyya did not reject reason, rather he tried to balance reason and textual sources, with the emphasis on literal sources regarding God's attributes. ${ }^{83}$ While many of the Hanbalites avoided rational arguments to defend their creeds, Ibn Taymiyya used different strategy to enforce literalism. He took advantages of rational arguments to prove that the rational approach itself was inadequate to explain basic theological belief.

The emphasis on literality marked the nature of Hanbalite theological discourse. To use of ta'wil (the interpretation of text) was the central of disputes between Hanbalites and its oppponents. The Hanafites and the Shafi'ites were quite familiar with of rationalism in Islamic law. Hanafite frequently used ra'y (rational deduction) so that they are better known as ahlal-ra'y (the rationalists), while the Shafi 'ite attempted to compromise the traditionists' and the rationalists' approaches. In Baghdad, the Hanbalites criticized the Hanafites 
who embrace Mu'tazila, while the Shafi'ite embraced Ash'arite. ${ }^{84}$ Later, the Hanafites prefered Maturidite, after all Islamic orthodoxy camps put Mu'tazila as their antithesis and Shafi'ite authorities turned to be Ash'arite proponents.

The Hanbalite represented traditionalists' beliefs. The Hanbalite strongly disapproved speculative theology (kalam) and esoteric-philosophical sufism. Hanbalite scholars did not attach to any other theological school like Shafi'ite and Hanafite did because Hanbalite acted as theological school as well. The Hanbalite was not homogeneous entity since Ibn Qudama criticized Ibn 'Aqil for having Ash'arite tendencies and Ibn al-Jawzi had different views than that of Abu Ya'la (d. 458H/ 1066AD), Abu al-Hasan al-Zaghuni (d. 527H/1132AD) and Abd al-Qadir al-Jilani (d. 561H/1166AD). ${ }^{85}$

Despite of their difference, the Hanbalites generally took position as the defender of salaf creeds that put them as an alternative school among other theological schools in Islam.

\section{CONCLUSION}

Hanbalite creeds marked an unique portrait of the Hanbalite as being both legal and theological schools. The school of Islamic law grew from the discourse of Islamic law followed by the application of the opinions in court and in Islamic madrasahs. Known as traditionists, Hanbalites gradually gained acknowledgment as a legal and theological movement. The position of the Hanbalite as legal school was is so prevalent that its position as theological school failed to be taken into account frequently.

The Hanbalite creeds and movement was laid down by Ahmad Ibn Hanbal. The creeds of Ahmad Ibn Hanbal went around the textual understanding of Islamic source in the matters of theology and the persistant position that alQuran is the words of God. Subsequently, Hanbalite scholars continued to elaborate and to defend the creeds against other theologians. Hanbalite scholars, such as al-Barbahari, Abu Ya'la, Ibn Qudama and Ibn Taymiyya carried out polemics against theologians from Mu'tazilite, Ash'arite, Jahmite, Shiite and philosopichal sufis. Through the polemics, the Hanbalite creeds was tested and elaborated more sophistically.

The article tried to extend previous research on Hanbalite theology by adding direct reference to Hanbalite theological treatises, narrating Hanbalite scholars' polemics against other theologians and portraiting the shift of the method of argument in hands of Ibnu Taymiyya. The article diachronically revealed the arguments of Hanbalite that shapes an distinctive stance of 
Hanbalite among other Islamic theological schools. The article, however, did not elaborate detailed arguments presented by each of Hanbalite scholars, rather it provides readers with the glimps of their acquintance to theological discourses in defending their creeds.

\section{END NOTE}

1 Eva Alexe. "The Relationship between the Salafist Current and The Wahhabite Movement.Proceeding of The 15th Edition of the International Conference, European Integration: Realities and Perspectives. (2000), pp 274

2 George Makdisi. Rise of Colledge: Institution of Learning in Islam and The West. Edinburgh: Edinburgh University Press. 1981), p. 2

3 George Makdisi. Rise of Colledge, p. 3,146

4 'Abd al-Rahman al-Jaziri. Kitab Al-Fiqh 'ala Madhahib al-Arba'a. (Beirut: Dar Ibn Hazm.. 2001)

5 Ahmad Zahro. Tradisi Intelektual NU, Lajnah Bahtsul Masa'il 1926 - 1999 (Yogyakarta: LKiS. 2004), p. 94-95

6 Sudarno, Syamsul Hidayat, Mahasri Shobahiya. Studi Kemuhammdiyahan: Kajian Historis, Ideologis, dan Organisasi. Surakarta: Lembaga Pengembangan Ilmu=Ilmu Dasar Universitas Muhammadiyah Surakarta. 2010), p. 6-9

7 Rahmat Abd. Rahman. "Latar Belakang Sosial Lahirnya Mazhab Hanbali." Busthanul Fuqaha, Jurnal Bidang Hukum Islam. Vol. I, No. 3 (2020) 505-515

8 Nabila Mouline. The Clerics of Islam: Religious and Political Power in Saudi Arabia (Yale: Yale University Press. 2014), p. 27 and Abu Hamid al-Ghazzali. Faysal alTafriqah bayn al-Islam wa al-Zandaqa. (T.Tp: Dar al-Bayruti. 1992), p. 19-22

9 Christopher Melchert. Ahmad bin Hanbal (Oxford: OneWorld. 2006), p. 9-12

10 Mohd. Hameedullah Khan. The Schools of Islamic Yurisprudence (New Delhi: Kitab Bhavan, Ed. III, 2001); 'Abd al-Rahman al- Jaziri. Kitab Al-Fiqh 'ala Madhahib al-Arba'a. (Beirut: Dar Ibn Hazm. 2001); and Salih Ibn 'Abd al-'Aziz al-Uthaymin. Tashil al-Sabila li Murid Ma'rifa al-Hanabila. (Beirut: Muassasah alRisala. 2000)

11 "The Advesaries of Ahmad bin Hanbal." Arabica T. 44, Fasc. 2 (April 1997)

12 Christopher Melchert. "Ahmad bin Hanbal and the Qur'an." Joumal of Quranic Studies. Vol. 6, No. 2 (2004) 22-34

13 Christopher Melchert. "The Hanabila and the Early Sufis”. Arabica T. 48, Fasc. 3 (2001), p. 352-367

14 Aziz al-Azmeh. "Ortodoxy and Hanbalite Fideism." Arabica T. 35, Fasc. 3 (Nov. 1988), p. 253-266

15 Wesley Williams. "Aspects of the Creed of Imam Ahmad bin Hanbal: A Study of Anthropomorphism in Early Islamic Discourse." International Journal of Middle East Studies. Vol. 34, No. 3 (Aug, 2003), p. 455-456

16 Kuntowijoyo. Metodologi Sejarah (Yogyakarta: Tiara Wacana. 1994), p. 37-38

17 Abdul Hakim I. Matroudi. The Hanbali School of Law and Ibn Taymiyyah: Conflict 
or Conciliation (London and New York: Routledge. 2006), p. 13

18 Abu Ya'la al-Farra', Tabaqat al-Hanabila. Jilid I, II. (Kairo: Matba'a al-Sunnah al-Muhammadiya. T.Th), p. 6

19 Nimrod Hurvitz. The Formation of Hanbalism: Piety into Power (New York: Routledge. 2002), p. 78

20 Abdul Hakim I. Matroudi. The Hanbali School, p. 13

21 Syafiq Mughni. Hanbali Movements in Bagdad from Abu Muhammad al-Barbahari (d. 329/941) to Abu Ja'far al-Hashimi (w. 470/1077) (Los Angeles. Dissertation Submitted in Partial Satisfaction of Requirement for the Degree Doctor of Philosophy in Islamic Studies The University of California. 1990), p. $97-99$ and Abu Ya'la. Tabaqat al-Hanabila, Vol. III, p. 256, 291, 333

22 George Makdisi. Rise of Colledge, p. 9

23 Bernard Lewis, Ch. Pellat, dan J. Schacht. The Encyclopaedia of Islam. Vol. IV. (Leiden dan London: E.J. Brill dan Luzac and CO, 1965), p. 159

24 Bernard Lewis, Pellat, and. Schacht. The Encyclopaedia, IV, p. 160-161

25 Bernard Lewis, Pellat, and. Schacht. The Encyclopaedia, IV, p. 159 and Mohd. Hameedullah Khan, The Schools of Islamic Yurisprudence (New Delhi: Kitab Bhavan, Ed. III, 2001), p. 115-116

26 Christopher Melchert. "The Advesaries," p. 235-237

27 Christopher Melchert. "The Advesaries, p. 239-241

28 Christopher Melchert. "The Advesaries, p. 241-243

29 Christopher Melchert. “The Hanabila.” p. 356, 359

30 Nabila Mouline. The Clerics of Islam, p. 25-27

31 Nimrod Hurvitz. The Formation of Hanbalism, 119-120 and Christopher Melchert. Ahmad bin Hanbal, p. 11-12

32 Nasihun Amin. Paradigma Teologi Politik Sunni: melacak Abu al-Hasan al-Asy'ari sebagai Perintis Pemikiran Politik Islam. (Yogyakarta: Pustaka Pelajar, 2015), p. 26-30

33 Abu al-Hasan 'Ali Ibn Isma'il Al-Ash'ari. Al-Ibana 'an Usul al-Diyana. (Kairo: Idarah al-Taba'a al-Muniriyyah. T.Th), p. 6-8 and George Makdisi. "Ash'ari and the Ash'arites in Islamic Religious History.” Studia Islamica No. 17 (1962), p. 41 42

34 Tim Winter (ed.). The Cambridge Companion to Classical Islamic Theology (Cambridge: Cambridge University Press. 2008), p. 53 and George Makdisi, Rise of Colledge, p. 39

35 Abu al-Hasan 'Ali Ibn Isma'il Al-Ash'ari. Al-Ibana, p. 6-8

36 Ignaz Goldziher. Introduction to Islamic Theology and Law (New Jersey: The University of Princeton. 1981), p. 92-93

37 Nasihun Amin. Paradigma Teologi, p. 34, 79-81

38 W. Montgomery Watt. Islamic Philosophy and Theology, an Extended Survey. Edinburgh: Edinburg University Press, 1985), p. $48-49$

39 W. Montgomery Watt. Islamic Philosophy, p. 49-50

40 Abu Ya'la al-Farra'. Al-Mu'tamad fi Usul al-Din (Beirut: Dar al-Mashriq. 1974), p. 293-296 
41 Tim Winter (ed.). The Cambridge Companion, p. 52

42 Wesley Williams. "Aspects of the Creed", p. 455-456

43 Abu Ya'la al-Farra'. Tabaqat al-Hanabila, II. P. 298

44 Abu Ya'la al-Farra'. Tabaqat al-Hanabila,, II, p. .299

45 Montgomery W. Watt. Islamic Philosophy, p. 50-51

46 Abu Ya'la al-Farra'. Tabaqat al-Hanabila,, II, p.301-302

47 Abdul Hakim I. Matroudi. The Hanbali School, p. 18-19

48 Abu Ya'la al-Farra'. Tabaqat al-Hanabila,, II, p. 302-303

49 Rubini. "Khawarij dan Murji'ah dalam Perspektif Ilmu Kalam." Jumal Komunikasi dan Pendidikan. Volume 7, Number 1 (June, 2018), pp. 105-107

50 Abu Bakr Ahmad Ibn Muhammad al-Khallal. Ahkam Ahl al-Milal min al-Jami' li Masa'il al-Imam Ahmad Ibn Hanbal (Beirut: Dar al-Kutub al-'Ilmiyya. 1994)

51 Abdullah Ibn Muhammad Ibn Ahmad al-Turiqi. Al-Hanabila Khiyala Thalatha 'Ashara Qarnan. Juz I. (Riyad: Maktaba al-Mulk Fahd al-Wataniyya. 2012), p. $40-41$

52 George Makdisi. Rise of Colledge, p. 128

53 Abu Bakr Ahmad Ibn Muhammad al-Khallal. Ahkam Ahl al-Milal, p. 5-9

54 Hamud Ibn Ibrahim al-Salama. Al-Masa'il al-Aqdiyya allati Khalafa fiha Ba'd Fuqaha al-Hanabila Imam al-Madhhab (Mesir: Dar al-Huda al-Nabawi. 2014), p. 23

55 Binyamin Abrahamov. "The "Bi-la Kayfa" Doctrine and Its Foundation in Islamic Theology.” Arabica T. 42 Fasc. 3 (Nov. 1995), pp. 366

56 Abu Muhammad al-Hasan Ibn 'Ali Ibn Khalaf al-Barbahari. Sharh al-Sunna. (Madina Munawwara: Maktaba al-Ghuraba' al-Athariyya. 1993), p. 70-71

57 Abu Ya'la al-Farra'. Al-Mutamad, p. 267-268

58 Ibn Qudama. Lum'a al-I'tiqad al-Hadi ila Sabil al-Rashshad. (Riyad: Adwa' alSalaf. 1995)

59 Muhammad Ibn Salih al-'Uthaymin. Sharh Lum'ah al-I'tiqad (Riyad: Maktaba Adwa' al-Salaf. 1995)

60 Mohammad Syifa Amin Widigdo. "Imam al-Haramayn a-Juwayni and Jadal Theory in The Eleventh Century: a Critical Analysis of Imam al-Haramayn's alKafiya fi al-Jadal.” Qudus International Journal of Islamic Studies. Vl. 6, Iusse 2, Agustus (2018), pp. 306-307

61 Salih Ibn 'Abd al-'Aziz Al-'Uthaymin. Tashil al-Sabila li Murid Ma'rifa al-Hanabila. (Beirut: Muassasah al-Risala. 2000), p. 89-93

62 Syafiq Mughni. Hanbali Movements, p. 157-165

63 Syafiq Mughni. Hanbali Movements, p. 182-183

64 Abu Ya'la al-Farra', al-Mu'tamad, p. 24-25

65 Abu Ya'la al-Farra'. Ibtal al-Ta'wilat li Akhbar al-Sifat. Juz I. (Kuwayt: Dar al-'Ilaf al-Hawliya. T.Th), p. 42-43

66 Syafiq Mughni. Hanbali Movements, p. 197-199

67 Mohammad Syifa Amin Widigdo. "Imam al-Haramayn a-Juwayni, p. 183

68 George Makdisi. “Ash'ari and the Ash'arites in Islamic Religious History.” Studia Islamica No. 17 (1962), p. 46 
69 George Makdisi. "Ash'ari and the Ash'arites.” PP. 47 and Abu Hamid al-Ghazzali. Faysal al-Tafriqa, p. 19-22

70 Ignaz Goldziher, An Introduction, p. $92-93$

71 Ibn Qudama. Rawda al-Nazir wa Junna al-Munazir. (Beirut: Dar al-Kutub al'Ilmiyya. 1994), p. 4-16

72 Ibn Qudama. Munazara fi al-Qur'an al-Azim (Kuwayt: Maktaba Ibn Taymiyya. 1990a), p. 32, 82, 83

73 Ibn Qudama. Ithbat Sifa al-Uluw. (Kuwayt: al-Dar al-Salafiyya. 1987) and Ibn Qudama. Munazara fi al-Qur'an al-Azim. (Kuwayt: Maktaba Ibn Taymiyya. 1990a), p. $72-73$

74 Ibn Qudama. Tahrim al-Nazar fi Kutub al-Kalam. (Riyad: Dar 'Alam al-Kutub. 1990b), p. 30-35

75 Abdul Hakim I. Matroudi. The Hanbali School, p. 18-19

76 Ibn Taymiyya. al-Fatwa al-Hamawiyya al-Kubra (Riyad: Dar al-Shamai. 1998), p. $62-63$

77 Ibn Taymiyya. Dar' Ta'arud al'Aql wa al-Naql. Juz I, V, VII (Madina: Idara alThaqafa wa al-Nashr bi al-Jami'a al-Madina. 1991)

78 Ibn Taymiyya. Dar' Ta'arud al-Aql wa al-Naql, VII, p. 105-106

79 Ayman Shihadeh. "From al-Ghazali to al-Razi: 6th/ 12th Century Developments in Muslim Philosophical Theology." Arabic Sciences and Philosophy Vol. 15 (2005), pp. 141-179

80 Yahya J. Michot. "A Mamluk Theologian's Commentary on Avicenna's "Risala Adhawiya": Being A Translation of A Part of The "Dar' al-Ta'arud" of Ibn Taimiyya with Introduction, Annotation, and Appendices Part I. Journal of Islamic Studies Vol. 14, No. 2 (May 2003), p. 149-203

81 Abu Hamid al-Ghazzali. Al-Mustasfa fi 'Ilm al-Usul. (Beirut: Dar al-Kutub al'Ilmiyya. 2000), p. 10

82 Ibn Taymiyya. Al-Radd 'ala al-Mantiqiyyin. (Bombay: Sharf al-Din al-Kutba wa Awladih. 1949),p. 14-15

83 Ibn Taymiyya. Dar' Ta'arud al-Aql wa al-Naql, VIII, p. 3-9

84 George Makdisi. Hanbalite Islam, dalam Merlin L. Swartz (Ed). "Studies on Islam” (New York dan Oxford: Oxford University Press. 1988), p. 239

85 George Makdisi. Hanbalite Islam, p. 241-249

\section{REFERENCE}

Abrahamov, Binyamin. "The "Bi-la Kayfa" Doctrine and Its Foundation in Islamic Theology.” Arabica T. 42 Fasc. 3 (Nov. 1995)

Alexe, Eva. "The Relationship between the Salafist Current and The Wahhabite Movement.Proceeding of The 15th Edition of the International Conference, European Integration: Realities and Perspectives. (2000). 272-278

Amin, Nasihun. Paradigma Teologi Politik Sunni: melacak Abu al-Hasan al-Asy'ari sebagai Perintis Pemikiran Politik Islam. Yogyakarta: Pustaka Pelajar, 2015

Ash'ari, Abu al-Hasan 'Ali Ibn Isma'il Al-. Al-Ibana 'an Usul al-Diyana. Kairo: Idarah al-Taba'a al-Muniriyyah. T.Th 
Azmeh, Aziz al-. "Ortodoxy and Hanbalite Fideism.” Arabica T. 35, Fasc. 3 (Nov. 1988), p. 253-266

Barbahari, Abu Muhammad al-Hasan Ibn 'Ali Ibn Khalaf al-. Sharh al-Sunna. Madina Munawwara: Maktaba al-Ghuraba’ al-Athariyya. 1993

Farra', Abu Ya'la al-. Ibtal al-Ta'wilat li Akhbar al-Sifat. Juz I. Kuwayt: Dar al-'Ilaf alHawliya. T.Th

Farra', Abu Ya'la al-. Al-Mu'tamad fi Usul al-Din. Beirut: Dar al-Mashriq. 1974

Farra', Abu Ya'la al-, Tabaqat al-Hanabila. Jilid I, II. Kairo: Matba'a al-Sunnah alMuhammadiya. T.Th

Goldziher, Ignaz. Introduction to Islamic Theology and Law. New Jersey: The University of Princeton. 1981

Ghazzali, Abu Hamid al. Faysal al-Tafriqah bayn al-Islam wa al-Zandaqa. (T.Tp: Dar al-Bayruti. 1992Hurvitz, Nimrod. The Formation of Hanbalism: Piety into Power. New York: Routledge. 2002

Jaziri, 'Abd al-Rahman al- . Kitab Al-Fiqh 'ala Madhahib al-Arba'a. Beirut: Dar Ibn Hazm. 2001

Khallal, Abu Bakr Ahmad Ibn Muhammad al-. Ahkam Ahl al-Milal min al-Jami' li Masa'il al-Imam Ahmad Ibn Hanbal. Beirut: Dar al-Kutub al-'Ilmiyya. 1994

Khan, Mohd. Hameedullah, The Schools of Islamic Yurisprudence, New Delhi: Kitab Bhavan, Ed. III, 2001

Kuntowijoyo. Metodologi Sejarah. Yogyakarta: Tiara Wacana. 1994

Lewis, Bernard Ch. Pellat, dan J. Schacht. The Encyclopaedia of Islam. Vol. IV. Leiden dan London: E.J. Brill dan Luzac and CO, 1965

Makdisi, George. "Ash'ari and the Ash'arites in Islamic Religious History." Studia Islamica No. 17 (1962)

Makdisi, George. Hanbalite Islam, dalam Merlin L. Swartz (Ed), "Studies on Islam”. New York dan Oxford: Oxford University Press. 1988

Makdisi, George, Rise of Colledge: Institution of Learning in Islam and The West. Edinburgh: Edinburgh University Press. 1981

Matroudi, Abdul Hakim I.. The Hanbali School of Law and Ibn Tayamiyyah: Conflict or Conciliation. London and New York: Routledge. 2006

Melchert, Christopher. Ahmad Ibn Hanbal. Oxford: OneWorld. 2006

Melchert, Christopher. “Ahmad Ibn Hanbal and the Qur'an.” Journal of Quranic Studies. Vol. 6, No. 2 (2004) 22-34

Melchert, Christopher. "The Adversaries of Ahmad bin Hanbal.” Arabica T. 44, Fasc. 2 (April 1997), 235-237

Melchert, Christopher. "The Hanabila and the Early Sufis”. Arabica T. 48, Fasc. 3 (2001), 352-367

Michot, Yahya J. “A Mamluk Theologian's Commentary on Avicenna's "Risala Adhawiya”: Being A Translation of A Part of The "Dar' al-Ta'arud" of Ibn Taimiyya with Introduction, Annotation, and Appendices Part I. Journal of Islamic Studies Vol. 14, No. 2 (May 2003)

Mouline, Nabila. The Clerics of Islam: Religious and Political Power in Saudi Arabia. Yale: Yale University Press. 2014 
Mughni, Syafiq. Hanbali Movements in Bagdad from Abu Muhammad al-Barbahari (d. 329/941) to Abu Ja'far al-Hashimi (w. 470/1077) Los Angeles. Dissertation Submitted in Partial Satisfaction of Requirement for the Degree Doctor of Philosophy in Islamic Studies The University of California. 1990.

Qudama, Ibn. Ithbat Sifa al-Uluw. Kuwayt: al-Dar al-Salafiyya. 1987

Qudama, Ibn. Lum 'a al-I'tiqad al-Hadi ila Sabil al-Rashshad. Riyad: Adwa' al-Salaf. 1995

Qudama, Ibn. Munazara fi al-Qur'an al-Azim. Kuwayt: Maktaba Ibn Taymiyya. 1990a

Qudama, Ibn. Rawda al-Nazir wa Junna al-Munazir. Beirut: Dar al-Kutub al-'Ilmiyya. 1994

Qudama, Ibn. Tahrim al-Nazar fi Kutub al-Kalam. Riyad: Dar 'Alam al-Kutub. 1990b

Rahman, Rahmat Abd. "Latar Belakang Sosial Lahirnya Mazhab Hanbali." Busthanul Fuqaha, Jurnal Bidang Hukum Islam. Vol. I, No. 3 (2020) 505-515

Rubini. "Khawarij dan Murji'ah dalam Perspektif Ilmu Kalam.” Jurnal Komunikasi dan Pendidikan. Volume 7, Number 1 (June, 2018), 95-114

Salama, Hamud Ibn Ibrahim al-. Al-Masa'il al-Aqdiyya allati Khalafa fiha Ba'd Fuqaha al-Hanabila Imam al-Madhhab. Mesir: Dar al-Huda al-Nabawi. 2014

Al-Sasan, Saud Saleh. "Early Muslim Traditionalism: A Critical Study of the Works and Political Theology of Ahmad bin Hanbal." A Thesis for the degree of doctor of Philosophy in Arab and Islamic Studies. The University of Exeter. 2011

Shihadeh, Ayman. "From al-Ghazali to al-Razi: 6th/ 12th Century Developments in Muslim Philosophical Theology." Arabic Sciences and Philosophy Vol. 15 (2005) $141-179$

Sudarno, Syamsul Hidayat, Mahasri Shobahiya, 2010. Studi Kemuhammadiyahan: Kajian Historis, Ideologis, dan Organisasi. Surakarta: Lembaga Pengembangan Ilmu-Ilmu Dasar Universitas Muhammadiyah Surakarta

Taymiyya, Ibn. al-Fatwa al-Hamawiyya al-Kubra. Riyad: Dar al-Shamai. 1998

Taymiyya, Ibn. Al-Radd 'ala al-Mantiqiyyin. Bombay: Sharf al-Din al-Kutba wa Awladih. 1949

Taymiyya, Ibn. Dar' Ta'arud al-Aql wa al-Naql. Juz I, V, VII. Madina: Idara al-Thaqafa wa al-Nashr bi al-Jami'a al-Madina. 1991

Turiqi, Abdullah Ibn Muhammad Ibn Ahmad al-. Al-Hanabila Khiyala Thalatha 'Ashara Qarnan. Juz I. Riyad: Maktaba al-Mulk Fahd al-Wataniyya. 2012

Uthaymin, Salih Ibn 'Abd al-'Aziz al-. Sharh Lum'a al-I'tiqad. Riyad: Maktaba Adwa' al-Salaf. 1995

Uthaymin, Salih Ibn 'Abd al-'Aziz al-. Tashil al-Sabila li Murid Ma'rifa al-Hanabila. Beirut: Muassasah al-Risala. 2000

Watt, W. Montgomery. Islamic Philosophy and Theology, an Extended Survey. Edinburgh: Edinburg University Press, 1985

Widigdo, Mohammad Syifa Amin. "Imam al-Haramayn a-Juwayni and Jadal Theory in The eleventh Century: a Critical Analysis of Imam al-Haramayn's al-Kafiya fi al-Jadal." Qudus International Journal of Islamic Studies. Vl. 6, Iusse 2, Agustus (2018)

Williams, Wesley. "Aspects of the Creed of Imam Ahmad bin Hanbal: A Study of 
Anthropomorphism in Early Islamic Discourse." International Journal of Middle East Studies. Vol. 34, No. 3 (Aug, 2003)

Winter, Tim (ed.). The Cambridge Companion to Classical Islamic Theology Cambridge: Cambridge University Press. 2008

Zahro, Ahmad. Tradisi Intelektual NU, Lajnah Bahtsul Masa'il 1926 - 1999, Yogyakarta: LKiS. 2004 